\title{
Mineral Chemistry and Geothermometry of Amphibole and Plagioclase in the Metabasites, Located at the Tanbour Metamorphic Complex in Southern Iran
}

\author{
Kasra Safei ${ }^{*}$, Mohammad-Ali Arian', Seyed Hesam-Aldin Moien Zadeh Mirhosseini' ${ }^{2}$ \\ ${ }^{1}$ Department of Geology, Faculty of Science, North Tehran Branch, Islamic Azad University, Tehran, Iran \\ ${ }^{2}$ Department of Geology, Faculty of Science, Kerman Branch, Shahid Bahonar University, Kerman, Iran \\ Email: *kasra_geology_s@yahoo.com
}

Received 4 October 2015; accepted 27 November 2015; published 30 November 2015

Copyright (C) 2015 by authors and Scientific Research Publishing Inc.

This work is licensed under the Creative Commons Attribution International License (CC BY). http://creativecommons.org/licenses/by/4.0/

\section{(c) (i) Open Access}

\begin{abstract}
Metabasite refers to metamorphosed basalts and other mafic igneous rocks (rich in iron and magnesium). When a mafic igneous rock is subjected to new pressure and temperature conditions during metamorphism, these chemical components will rearrange themselves to form new minerals. Metabasites can be found in many metamorphic belts including Sanandaj-Sirjan metamorphic belt of Iran. The study area is a Tanbour metamorphic complex in Eastern of Sirjan city, which is geologically located at the Sanandaj-Sirjan metamorphic belt in Southern Iran. Metabasite in this complex consists of greenschist, epidote amphibolite and amphibolite. Amphibole and plagioclase are the main minerals in the greenschist and amphibolite, and the a secondary mineral in some micaschist seen in the study area. The electron microprobe analysis was done on this mineralization in greenschist, epidote amphibolite and amphibolite, which showed that the amphiboles in greenschist was a member of the calcic group and Actinolite type, and the amphiboles in epidote amphibolite was a member of the calcic group and these amphiboles were tschermakite up to Ferro-Tschermakite + Ferro-Hornblende type. The amphibole in amphibolite is a member of the calcic group and this amphibole is Magnesio-Hornblende type. The plagioclases in the greenschist is pure albite (An 3.29 - 3.6), and in the epidote amphibolite is oligoclase (An 19.5 - 24.2), while in the amphibolites is oligoclase (An 16.9 - 26.6). The estimated P-T conditions are in favor of their metamorphism under epidote amphibolite $\left(550^{\circ} \mathrm{C}\right.$ and $\left.8 \mathrm{kbar}\right)$ and amphibolite $\left(611^{\circ} \mathrm{C}-652^{\circ} \mathrm{C}\right.$ and 10.5 kbar) facies.
\end{abstract}

\footnotetext{
${ }^{*}$ Corresponding author.
}

How to cite this paper: Safei, K., Arian, M.-A. and Moien Zadeh Mirhosseini, S.H.-A. (2015) Mineral Chemistry and Geothermometry of Amphibole and Plagioclase in the Metabasites, Located at the Tanbour Metamorphic Complex in Southern Iran. Open Journal of Geology, 5, 795-808. http://dx.doi.org/10.4236/ojg.2015.511068 


\section{Keywords}

\section{Metabasite, Amphibole, Plagioclase, Mineral Chemistry, Tanbor Metamorphic Complex, Sanandaj-Sirjan Metamorphic Belt}

\section{Introduction}

Metabasite are important metamorphic rocks which are sensitive to the condition of metamorphism and can be used to estimate the pressure and temperature of metamorphism. Basalts and gabbros are composed of calcic plagioclase along with ferromagnesian minerals such as hornblende, augite, enstatite, and olivine. Thus mafic igneous rocks can be characterized chemically as combinations of the following cations: $\mathrm{Si}, \mathrm{Al}, \mathrm{Ca}, \mathrm{Fe}$, and $\mathrm{Mg}$. When a mafic igneous rock is subjected to new pressure and temperature conditions during metamorphism, these chemical components will rearrange themselves to form new minerals. Which Fe-Mg-Ca-bearing silicates form depends on the specific pressure and temperature conditions, and so by identifying the minerals within a metabasite you can determine the approximate conditions under which the basalt or gabbro is metamorphosed. Several amphiboles are common in metabasites. Metabasites can be found in many metamorphic belts including Sanandaj-Sirjan metamorphic belt of Iran. The study area is a Tanbor metamorphic complex in eastern of Sirjan city, which is geologically located at the Sanandaj-Sirjan Metamorphic belt in southern Iran. Metabasite in this complex consists of greenschist, epidote amphibolite and amphibolite. This paper is based on mineral chemistry studies specifying the type of amphibole in metabasites.

\section{Geology of the Study Area}

The study area is located $25 \mathrm{~km}$ east of Sirjan in southern Iran (Figure 1), within the Sanandaj-Sirjan metamorphic belt (Figure 2(a)). There is no radiometric age determination on the rocks and the exact age of the metamorphism is not clear. The main lithological units of the region include slate, phyllite, micaschist, greenschist, amphibolite, dolomite-calcite marbles and quartzite. The sedimentary protoliths were turbiditic sandstone, carbonates and pelitic rocks, which are metamorphosed regionally up to amphibolite facies [1]. The outcrop of the pelitic rocks exceeds that of two other types. Minor magmatic activities generated basic igneous rocks, mainly dolerite. Regional metamorphism produced a variety of slates, phyllites, chlorite schists, actinolite schists, chloritoid schists, calc schists, marbles, mica schists, garnet schists and amphibolites [2]. Based on microfossil studies, Mijalkovic and Saric [3] concluded a Lower Permian age for phyllites and slates. Upper Permian rocks are garnet-mica schist, metadolerite, amphibole schist and amphibolite [2]. A block of ophiolitic rocks and Cretaceous limestone are located close to the palaeozoic metamorphic rocks by a strike-slip fault. Unmetamorphosed limestone of OligoMiocene covers the metamorphic rocks disconformably in the southern part of the studied area. (Figure 2(b)).

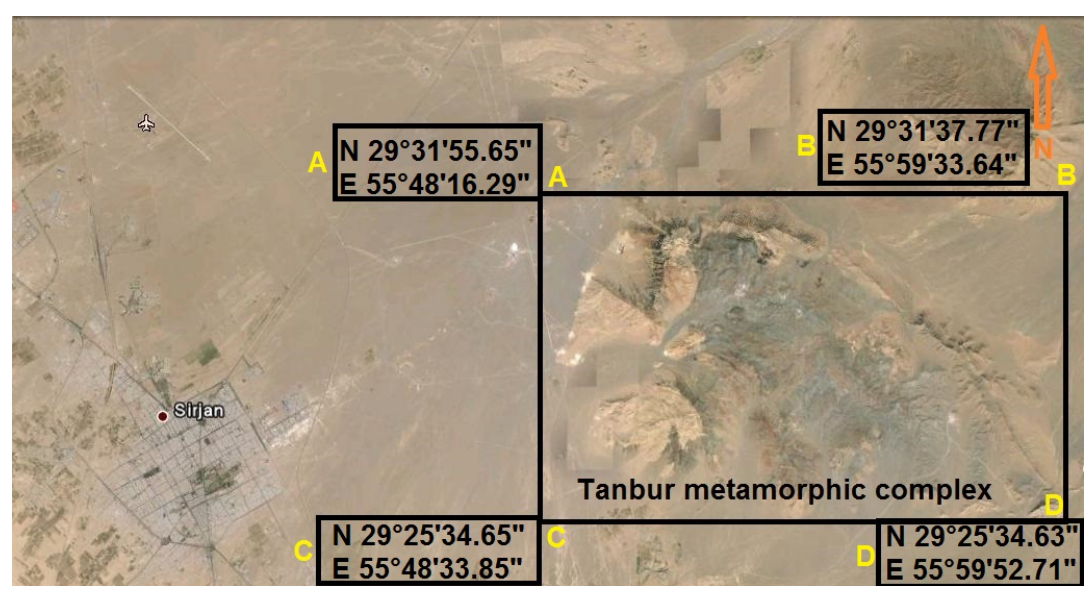

Figure 1. The study area with geographic coordinates in the satellite image. 


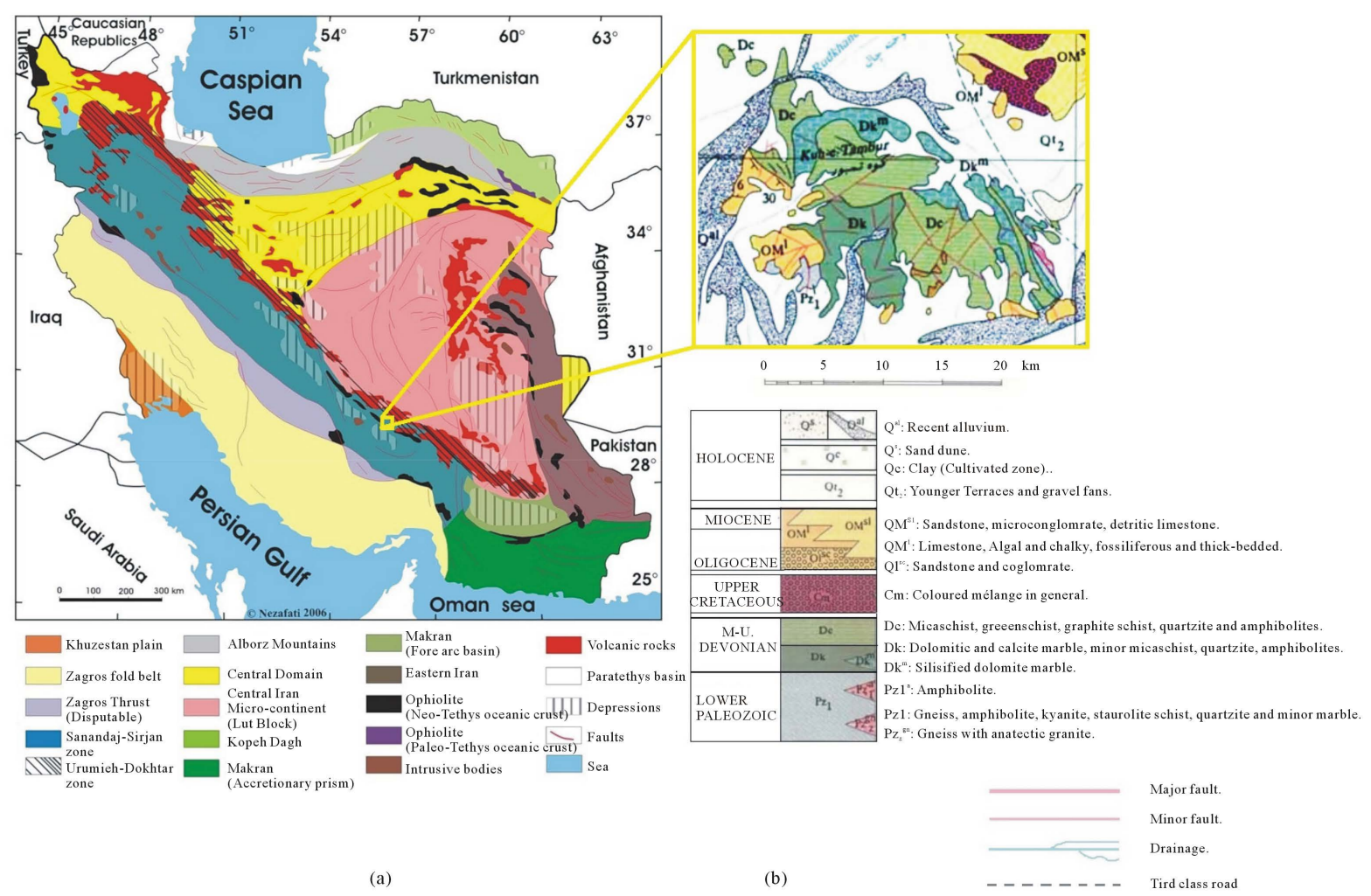

Figure 2. (a) Map of geological zone of Iran. (b) A part of simplified geological map of study area.

\section{Petrography}

Amphibole and plagioclase are the main minerals in the greenschist and amphibolite, and the secondary mineral in some micaschist seen in the area. Amphibole was seen in greenschist with paragenesis of actinolite + plagioclase + epidote + quartz \pm opaque minerals (magnetite), and the textures in the rocks are nematoblastic and granoblastic. The former is defined by an actinolite orientation and the latter by an inequigranular mosaic of epidote, plagioclase and quartz (Figure 3). The epidote amphibolite rocks with paragenesis of tschermakite up to ferro tschermakite + hornblende + epidote + plagioclase + quartz \pm opaque minerals are shown in Figure 4, Figure 5 and Figure 6. Plagioclase is often transformed to epidote in the epidote amphibolites (Figure 7). Amphibole in amphibolite rocks with paragenesis of hornblende + plagioclase + epidote + quartz + zoisite + clinozoisite + rutile \pm opaque minerals (magnetite) is shown in Figure 8. The amphiboles in amphibolite are tan to brown in color and arestrongly pleochroic. The textures found in these rocks are nematoblastic and granoblastic. The first texture is defined by hornblendes, the second one by plagioclase, quartz, and the epidote group (Figure 9).

\section{Mineral Chemistry of the Amphibole Bearing Metabasits}

The complex chemical composition of members of the amphibole group can be expressed by the general formula $A_{0-1} B_{2} C_{5} T_{8} \mathrm{O}_{22}(\mathrm{OH}, \mathrm{F}, \mathrm{Cl})_{2}$, where $A=\mathrm{Na}, \mathrm{K} ; B=\mathrm{Na}$, Zn, $\mathrm{Li}, \mathrm{Ca}, \mathrm{Mn}, \mathrm{Fe}^{2+}, \mathrm{Mg} ; \mathrm{C}=\mathrm{Mg}, \mathrm{Fe}^{2+}, \mathrm{Mn}, \mathrm{Al}, \mathrm{Fe}^{3+}$, $\mathrm{Ti}, \mathrm{Zn}, \mathrm{Cr}$; and $T=\mathrm{Si}, \mathrm{Al}$, Ti. Nearly complete substitution may take place between sodium and calcium and among magnesium, ferrous iron, and manganese (Mn). There is limited substitution between ferric iron and aluminum and between titanium and other $C$-type cations. Aluminum can partially substitute for silicon in the tetrahedral $(T)$ site. Partial substitution of fluorine (F), chlorine, and oxygen for hydroxyl (OH) in the hydroxyl site is also common. The complexity of the amphibole formula has given rise to numerous mineral names within the amphibole group. In 1997 Leake presented a precise nomenclature of 76 names that encompass the chemical variation within this group. The mineral nomenclature of the amphiboles is divided into four principal subdivisions based on $B$-group cation occupancy: 1) the iron-magnesium-manganese amphibole group; 2) the calcic amphibole group; 3) the sodic-calcic amphibole group, and 4) the sodic amphibole group (Figure 10) [4]. 


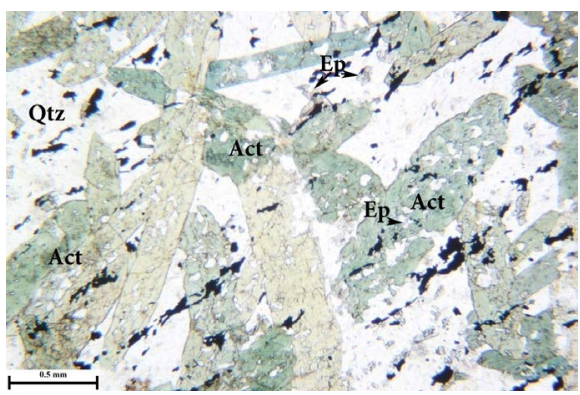

(a)

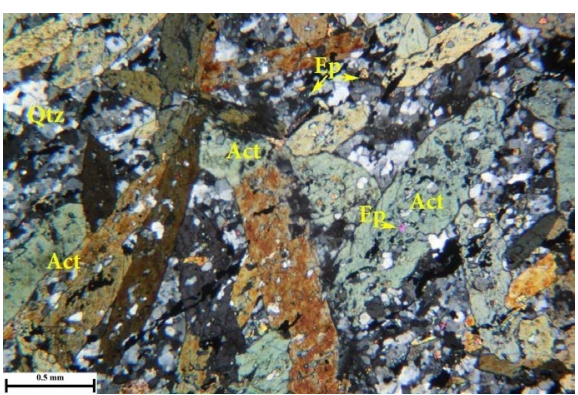

(b)

Figure 3. Microscopic image of actinolite schist, nematoblastic and decussate texture in this image can be seen. (a) PPL; (b) XPL.

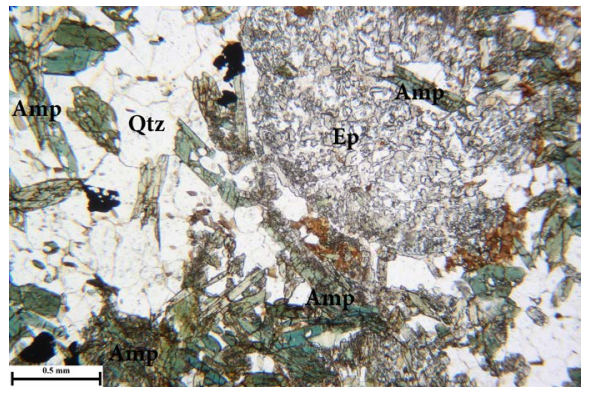

(a)

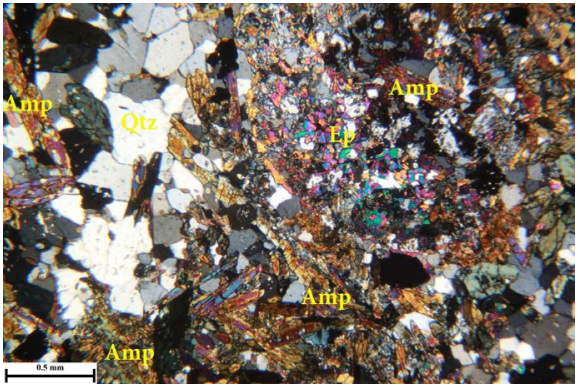

(b)

Figure 4. Microscopic image of epidote amphibolite, epidote and secondary quartz, which have recrystallization in this image can be seen. (a) PPL; (b) XPL.

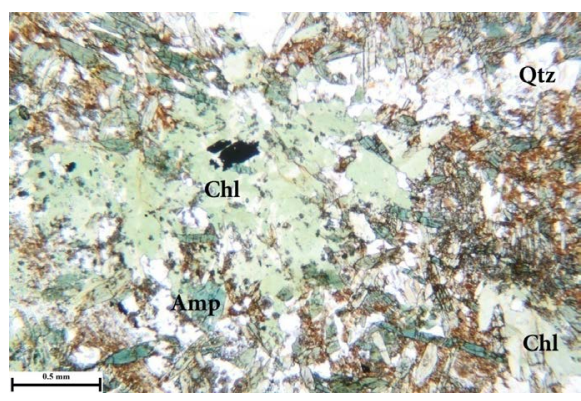

(a)

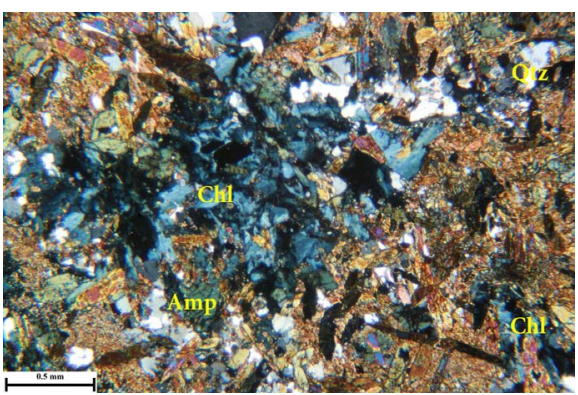

(b)

Figure 5. Microscopic image of epidote amphibolite, the accumulation of chlorite minerals, in this image can be seen. (a) PPL; (b) XPL.

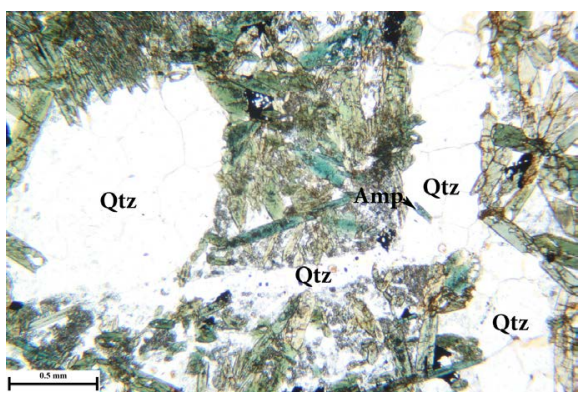

(a)

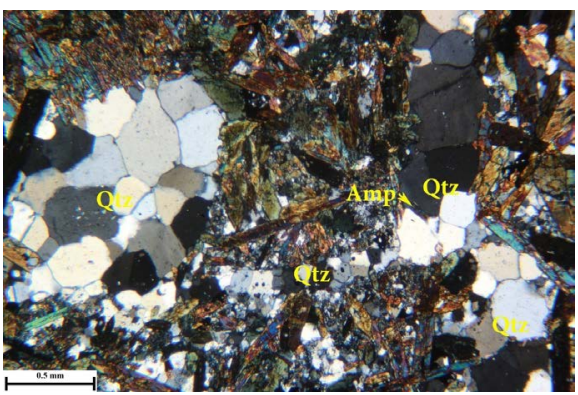

(b)

Figure 6. Microscopic image of epidote amphibolite, Secondary quartz veins, which have recrystallization and growth by phenomenon leakage filled cavities and have a ball shape, in this image can be seen. (a) PPL; (b) XPL. 


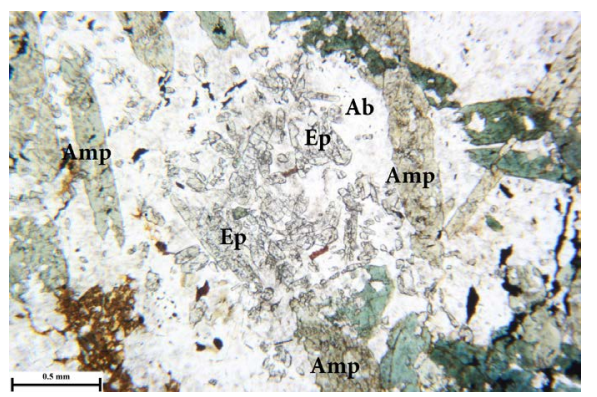

(a)

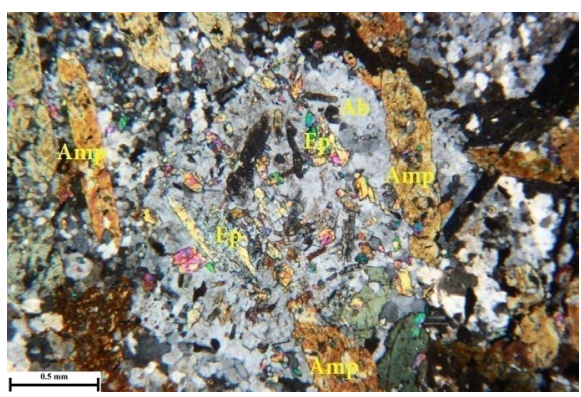

(b)

Figure 7. Microscopic image of epidote amphibolite, poikiloblastic texture, in this image can be seen. (a) PPL; (b) XPL.

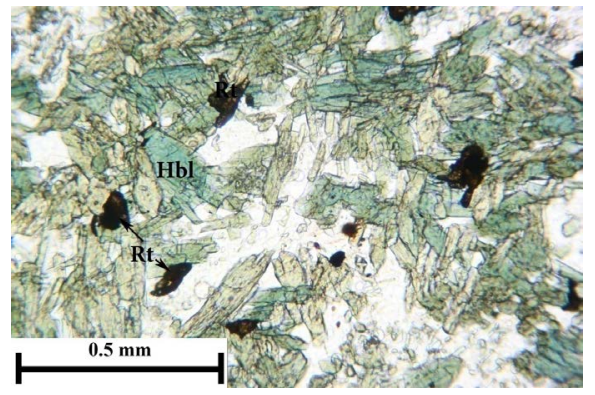

(a)

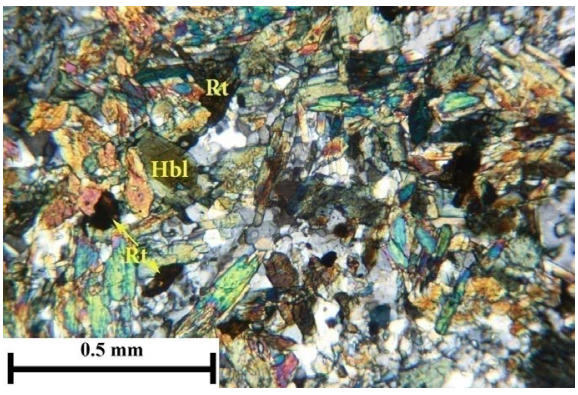

(b)

Figure 8. Microscopic image of amphibolite, hornblende and rutile minerals, in this image can be seen. (a) PPL; (b) XPL.

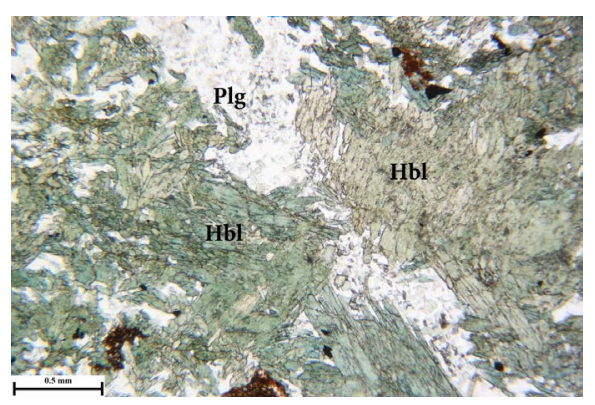

(a)

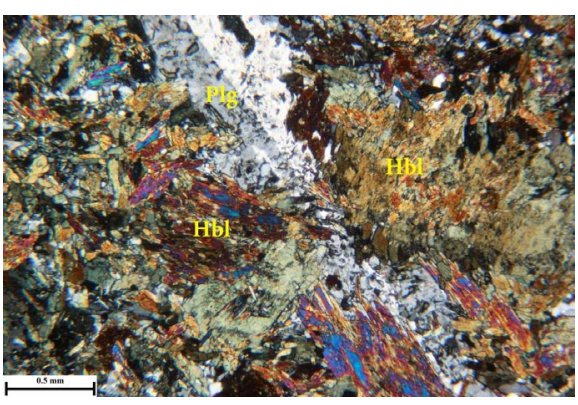

(b)

Figure 9. Microscopic image of amphibolite, plagioclase with Carlsbad-albite twins and hornblende in this image can be seen. (a) PPL; (b) XPL.

To determine the chemical composition of amphibole bearing metabasites in the study area, electron microprobe analysis were done on this mineralization in greenschist, epidote amphibolite and amphibolite. Table 1 includes the microprobe analyses of amphibole in the greenschist samples. Table 2 includes the microprobe analyses of amphibole in the epidote amphibolite samples. Table 3 includes the microprobe analyses of amphibole in the amphibolite samples.

Based on the results of electron microprobe analysis, first By the Minpet Software, The number of cations is recalculated on the basis of 23 oxygens from the Richard and Clarke [5] and Based on the iron type of $\mathrm{Fe}^{2+}$ from the Robinson et al. [6]. Table 4 includes the recalculated Result of amphibole in the greenschist samples. Table 5 includes the recalculated result of amphibole in the epidote amphibolite samples. Table 6 includes the recalculated result of amphibole in the amphibolite samples.

To determine the amphibole mineral groups in metabasites of the study area, chemical composition of the amphiboles analysed plotted on BNa on $\mathrm{BCa}+\mathrm{BNa}$ diagram. [7] According to this diagram (Figure 11), shows 


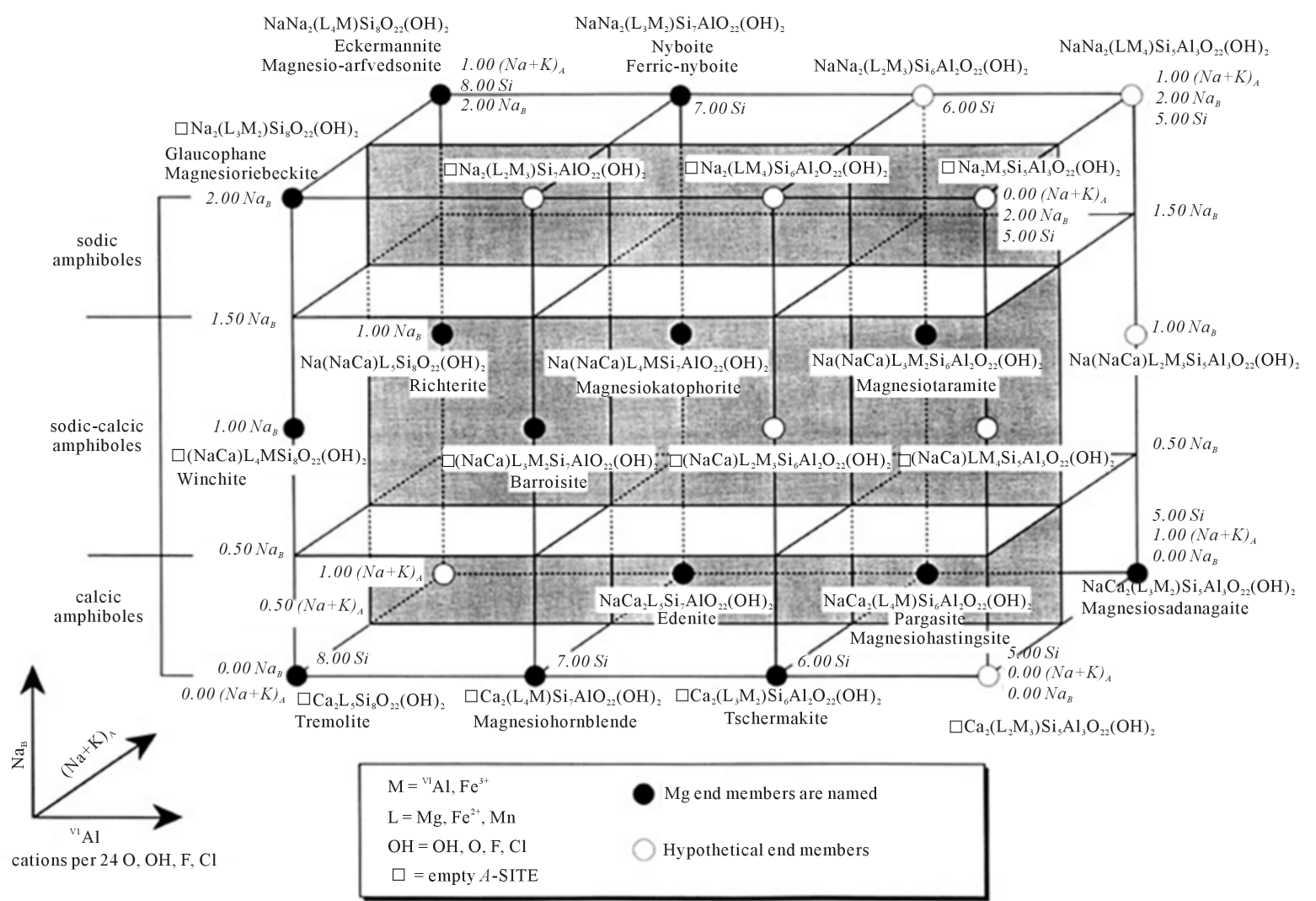

Figure 10. General classification of the amphiboles excluding the Mg-Fe-Mn-Li amphiboles [4].

Table 1. Microprobe analyses of amphibole in the greenschist samples.

\begin{tabular}{cccccccccccc} 
Sample & $\mathrm{H}_{2} \mathrm{O}$ & $\mathrm{Na}_{2} \mathrm{O}$ & $\mathrm{K}_{2} \mathrm{O}$ & $\mathrm{MgO}$ & $\mathrm{CaO}$ & $\mathrm{MnO}$ & $\mathrm{FeO}$ & $\mathrm{Al}_{2} \mathrm{O}_{3}$ & $\mathrm{SiO}_{2}$ & $\mathrm{TiO}_{2}$ & $\mathrm{Total}$ \\
\hline 1 & 1.56 & 0.06 & 0.09 & 11.68 & 10.9 & 0.5 & 18.1 & 4.9 & 52.8 & 0.4 & 100.99 \\
2 & 1.64 & 0.06 & 0.08 & 11.32 & 10.83 & 0.5 & 18.65 & 4.6 & 53.2 & 0.45 & 101.33 \\
3 & 1.35 & 0.03 & 0.07 & 11.44 & 11.08 & 0.3 & 18.93 & 4.2 & 53.18 & 0.6 & 101.18 \\
4 & 1.98 & 0.08 & 0.08 & 11.3 & 10.98 & 0.3 & 17.53 & 3.6 & 54.23 & 0.65 & 101.73 \\
5 & 1.89 & 0.07 & 0.08 & 11.56 & 10.86 & 0.28 & 18.47 & 4.1 & 53.86 & 0.68 & 101.85 \\
6 & 1.78 & 0.05 & 0.08 & 11.68 & 10.09 & 0.33 & 18.94 & 3.86 & 54.12 & 0.6 & 101.53 \\
7 & 1.74 & 1.69 & 0.08 & 11.3 & 11.1 & 0.3 & 17.7 & 3.7 & 53 & 0.7 & 101.31 \\
\hline
\end{tabular}

Table 2. Microprobe analyses of amphibole in the epidote amphibolite samples.

\begin{tabular}{ccccccccccccc}
\hline Formula & $\mathrm{H}_{2} \mathrm{O}$ & $\mathrm{Na}_{2} \mathrm{O}$ & $\mathrm{K}_{2} \mathrm{O}$ & $\mathrm{MgO}$ & $\mathrm{CaO}$ & $\mathrm{MnO}$ & $\mathrm{FeO}$ & $\mathrm{Al}_{2} \mathrm{O}_{3}$ & $\mathrm{SiO}_{2}$ & $\mathrm{TiO}_{2}$ & $\mathrm{Total}$ \\
\hline 1 & 2.03 & 1.55 & 0.58 & 10.54 & 11.02 & 0.01 & 13.87 & 13.35 & 42.28 & 0.77 & 96.01 \\
2 & 2.21 & 1.49 & 0.21 & 12.59 & 11.31 & 0.19 & 14.38 & 10.92 & 46.99 & 0.78 & 101.07 \\
3 & 2.07 & 1.62 & 0.34 & 9.98 & 11.55 & 0.15 & 15.06 & 13.88 & 42.36 & 0.44 & 97.44 \\
4 & 2.11 & 1.73 & 0.28 & 10.32 & 11.57 & 0.09 & 15.04 & 14.01 & 43.79 & 0.3 & 99.25 \\
5 & 2.12 & 1.55 & 0.27 & 10.34 & 11.72 & 0.03 & 15.07 & 13.72 & 44.35 & 0.16 & 99.32 \\
6 & 2.06 & 1.45 & 0.29 & 11.12 & 11.31 & 0.19 & 14.44 & 11.36 & 43.94 & 0.38 & 96.54 \\
7 & 2.14 & 1.89 & 0.42 & 10.71 & 11.59 & 0.18 & 15.17 & 14.7 & 43.4 & 0.67 & 100.86 \\
8 & 2.23 & 2.12 & 0.38 & 11.26 & 11.38 & 0 & 15.01 & 15.93 & 42.46 & 0.36 & 102.13 \\
9 & 2.13 & 1.92 & 0.3 & 10.15 & 11.44 & 0.24 & 15.41 & 15.06 & 43.32 & 0.4 & 100.37 \\
\hline
\end{tabular}




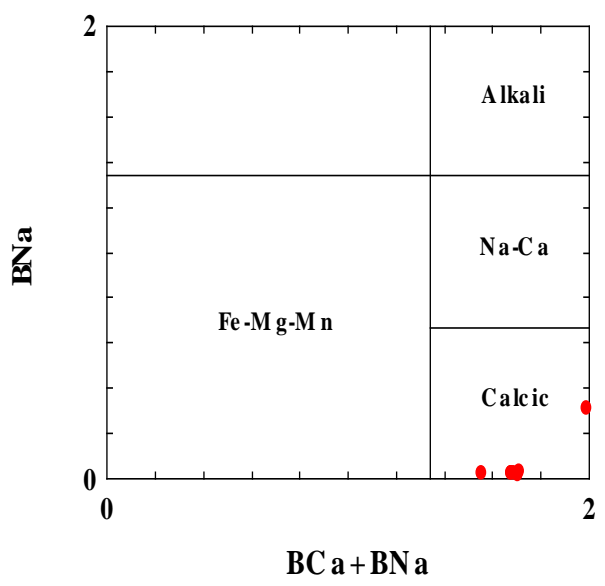

Figure 11. Chemical composition of the amphiboles analysed plotted on BNa on BCa + BNa diagram. The amphibole in greenschist is a member of the calcic group.

Table 3. Microprobe analyses of amphibole in the amphibolite samples.

\begin{tabular}{cccccccccccc}
\hline Formula & $\mathrm{H}_{2} \mathrm{O}$ & $\mathrm{Na}_{2} \mathrm{O}$ & $\mathrm{K}_{2} \mathrm{O}$ & $\mathrm{MgO}$ & $\mathrm{CaO}$ & $\mathrm{MnO}$ & $\mathrm{FeO}$ & $\mathrm{Al}_{2} \mathrm{O}_{3}$ & $\mathrm{SiO}_{2}$ & Total \\
\hline 1 & 2.07 & 1.62 & 0.59 & 4.54 & 11.25 & 0 & 22.66 & 16.34 & 41.51 & 100.59 \\
2 & 2.06 & 1.82 & 0.62 & 4.28 & 11.06 & 0.4 & 22.68 & 16.74 & 40.99 & 100.65 \\
3 & 2.08 & 1.66 & 0.78 & 4.33 & 11.21 & 0.11 & 22.25 & 17.4 & 41.13 & 100.95 \\
4 & 2.39 & 1.85 & 0.66 & 4.59 & 10.84 & 0.57 & 23.31 & 16.76 & 40.68 & 101.64 \\
5 & 2.06 & 1.68 & 0.71 & 4.27 & 11.16 & 0.3 & 22.92 & 16.6 & 41 & 100.71 \\
6 & 2.02 & 1.54 & 0.58 & 4.23 & 11.22 & 0.28 & 22.57 & 15.81 & 40.48 & 98.73 \\
7 & 2.1 & 1.69 & 0.64 & 4.57 & 11.38 & 0.32 & 22.39 & 16.96 & 42.04 & 102.09 \\
8 & 2.04 & 1.57 & 0.72 & 4.3 & 11.33 & 0 & 21.03 & 17.05 & 40.8 & 98.86 \\
9 & 2.06 & 1.69 & 0.65 & 4.35 & 11.23 & 0.1 & 22.38 & 16.89 & 41.03 & 100.38 \\
10 & 2.04 & 1.67 & 0.67 & 4.21 & 11.13 & 0 & 20.97 & 17.08 & 40.67 & 98.44 \\
\hline
\end{tabular}

Table 4. Recalculated result of amphibole in the greenschist samples.

\begin{tabular}{ccccccccccccccc}
\hline Sample & $\mathrm{TSi}$ & $\mathrm{TAl}$ & $\mathrm{TFe}_{3}$ & $\mathrm{TTi}$ & $\mathrm{Sum} \_\mathrm{T}$ & $\mathrm{CAl}$ & $\mathrm{CCr}$ & $\mathrm{CFe}_{3}$ & $\mathrm{CTi}$ & $\mathrm{CMg}$ & $\mathrm{CFe}_{2}$ & $\mathrm{CMn}$ & $\mathrm{CCa}$ & Sum_C \\
\hline 1 & 7.663 & 0.337 & 0 & 0 & 8 & 0.293 & 0 & 0 & 0.076 & 2.436 & 2.14 & 0.037 & 0.019 & 5 \\
2 & 7.607 & 0.393 & 0 & 0 & 8 & 0.439 & 0 & 0 & 0.043 & 2.509 & 2.009 & 0 & 0 & 5 \\
3 & 7.656 & 0.344 & 0 & 0 & 8 & 0.436 & 0 & 0 & 0.049 & 2.429 & 2.087 & 0 & 0 & 5 \\
4 & 7.655 & 0.345 & 0 & 0 & 8 & 0.367 & 0 & 0 & 0.065 & 2.455 & 2.113 & 0 & 0 & 5 \\
5 & 7.822 & 0.178 & 0 & 0 & 8 & 0.434 & 0 & 0 & 0.071 & 2.43 & 2.066 & 0 & 0 & 5 \\
6 & 7.71 & 0.29 & 0 & 0 & 8 & 0.402 & 0 & 0 & 0.073 & 2.467 & 2.058 & 0 & 0 & 5 \\
7 & 7.76 & 0.24 & 0 & 0 & 8 & 0.412 & 0 & 0 & 0.065 & 2.497 & 2.027 & 0 & 0 & 5 \\
\hline Sample & $\mathrm{BMg}$ & $\mathrm{BFe} 2$ & $\mathrm{BMn}$ & $\mathrm{BCa}$ & $\mathrm{BNa}$ & $\mathrm{Sum \_ B}$ & $\mathrm{ACa}$ & $\mathrm{ANa}$ & $\mathrm{AK}$ & $\mathrm{Sum} \_\mathrm{A}$ & $\mathrm{Sum} \_\mathrm{cat}$ & $\mathrm{CCl}$ & $\mathrm{CF}$ & Sum_oxy \\
\hline 1 & 0 & 0 & 0 & 1.701 & 0.299 & 2 & 0 & 0.175 & 0.015 & 0.189 & 15.189 & 0 & 0 & 22.999 \\
2 & 0 & 0.172 & 0.061 & 1.683 & 0.017 & 1.932 & 0 & 0 & 0.017 & 0.017 & 14.949 & 0 & 0 & 22.999 \\
3 & 0 & 0.158 & 0.061 & 1.67 & 0.017 & 1.905 & 0 & 0 & 0.015 & 0.015 & 14.92 & 0 & 0 & 22.999 \\
4 & 0 & 0.166 & 0.037 & 1.709 & 0.008 & 1.92 & 0 & 0 & 0.013 & 0.013 & 14.933 & 0 & 0 & 22.999 \\
5 & 0 & 0.049 & 0.037 & 1.697 & 0.022 & 1.804 & 0 & 0 & 0.015 & 0.015 & 14.819 & 0 & 0 & 22.999 \\
6 & 0 & 0.153 & 0.034 & 1.666 & 0.019 & 1.872 & 0 & 0 & 0.015 & 0.015 & 14.887 & 0 & 0 & 22.999 \\
7 & 0 & 0.244 & 0.04 & 1.55 & 0.014 & 1.848 & 0 & 0 & 0.015 & 0.015 & 14.863 & 0 & 0 & 22.999 \\
\hline
\end{tabular}


Table 5. Recalculated result of amphibole in the epidote amphibolite samples.

\begin{tabular}{ccccccccccccccc}
\hline Sample & $\mathrm{TSi}$ & $\mathrm{TAl}$ & $\mathrm{TFe}_{3}$ & $\mathrm{TTi}$ & $\mathrm{Sum} \_\mathrm{T}$ & $\mathrm{CAl}$ & $\mathrm{CCr}$ & $\mathrm{CFe}_{3}$ & $\mathrm{CTi}$ & $\mathrm{CMg}$ & $\mathrm{CFe}_{2}$ & $\mathrm{CMn}$ & CCa & Sum_C \\
\hline 1 & 6.296 & 1.704 & 0 & 0 & 8 & 1.215 & 0 & 0 & 0 & 1.027 & 2.758 & 0 & 0 & 5 \\
2 & 6.232 & 1.768 & 0 & 0 & 8 & 1.229 & 0 & 0 & 0 & 0.97 & 2.801 & 0 & 0 & 5 \\
3 & 6.211 & 1.789 & 0 & 0 & 8 & 1.306 & 0 & 0 & 0 & 0.975 & 2.719 & 0 & 0 & 5 \\
4 & 6.17 & 1.83 & 0 & 0 & 8 & 1.164 & 0 & 0 & 0 & 1.038 & 2.799 & 0 & 0 & 5 \\
5 & 6.056 & 1.944 & 0 & 0 & 8 & 0.944 & 0 & 1.348 & 0 & 0.94 & 1.484 & 0.038 & 0.247 & 5 \\
6 & 6.101 & 1.899 & 0 & 0 & 8 & 0.907 & 0 & 1.33 & 0 & 0.95 & 1.514 & 0.036 & 0.262 & 5 \\
7 & 6.274 & 1.726 & 0 & 0 & 8 & 1.255 & 0 & 0 & 0 & 1.017 & 2.729 & 0 & 0 & 5 \\
8 & 6.262 & 1.738 & 0 & 0 & 8 & 1.343 & 0 & 0 & 0 & 0.984 & 2.673 & 0 & 0 & 5 \\
9 & 6.237 & 1.763 & 0 & 0 & 8 & 1.261 & 0 & 0 & 0 & 0.986 & 2.753 & 0 & 0 & 5 \\
10 & 6.264 & 1.736 & 0 & 0 & 8 & 1.362 & 0 & 0 & 0 & 0.967 & 2.671 & 0 & 0 & 5 \\
\hline Sample & $\mathrm{BMg}$ & $\mathrm{BFe}$ & $\mathrm{BMn}$ & $\mathrm{BCa}$ & $\mathrm{BNa}$ & $\mathrm{Sum} \_\mathrm{B}$ & $\mathrm{ACa}$ & $\mathrm{ANa}$ & $\mathrm{AK}$ & $\mathrm{Sum} \_\mathrm{A}$ & $\mathrm{Sum} \_\mathrm{cat}$ & $\mathrm{CCl}$ & $\mathrm{CF}$ & Sum_oxy \\
1 & 0 & 0.116 & 0 & 1.828 & 0.055 & 2 & 0 & 0.421 & 0.114 & 0.535 & 15.535 & 0 & 0 & 22.996 \\
2 & 0 & 0.083 & 0.052 & 1.802 & 0.064 & 2 & 0 & 0.473 & 0.12 & 0.593 & 15.593 & 0 & 0 & 22.995 \\
3 & 0 & 0.091 & 0.014 & 1.814 & 0.081 & 2 & 0 & 0.405 & 0.15 & 0.555 & 15.555 & 0 & 0 & 22.995 \\
4 & 0 & 0.158 & 0.073 & 1.762 & 0.007 & 2 & 0 & 0.537 & 0.128 & 0.665 & 15.665 & 0 & 0 & 22.996 \\
5 & 0 & 0 & 0 & 1.519 & 0.481 & 2 & 0 & 0 & 0.134 & 0.134 & 15.134 & 0 & 0 & 23 \\
6 & 0 & 0 & 0 & 1.55 & 0.45 & 2 & 0 & 0 & 0.112 & 0.112 & 15.112 & 0 & 0 & 23 \\
7 & 0 & 0.066 & 0.04 & 1.82 & 0.074 & 2 & 0 & 0.415 & 0.122 & 0.537 & 15.537 & 0 & 0 & 22.996 \\
8 & 0 & 0.026 & 0 & 1.863 & 0.111 & 2 & 0 & 0.356 & 0.141 & 0.497 & 15.497 & 0 & 0 & 22.995 \\
9 & 0 & 0.092 & 0.013 & 1.829 & 0.066 & 2 & 0 & 0.432 & 0.126 & 0.558 & 15.558 & 0 & 0 & 22.995 \\
10 & 0 & 0.03 & 0 & 1.837 & 0.133 & 2 & 0 & 0.366 & 0.132 & 0.497 & 15.497 & 0 & 0 & 22.995 \\
\hline & & & & & & & & & & & & & & 5 \\
\hline
\end{tabular}

Table 6. Recalculated result of amphibole in the amphibolite samples.

\begin{tabular}{ccccccccccccccc}
\hline sample & $\mathrm{TSi}$ & $\mathrm{TAl}$ & $\mathrm{TFe}_{3}$ & $\mathrm{TTi}$ & $\mathrm{Sum} \_\mathrm{T}$ & $\mathrm{CAl}$ & $\mathrm{CCr}$ & $\mathrm{CFe}_{3}$ & $\mathrm{CTi}$ & $\mathrm{CMg}$ & $\mathrm{CFe}_{2}$ & $\mathrm{CMn}$ & $\mathrm{CCa}$ & Sum_C \\
\hline 1 & 6.469 & 1.531 & 0 & 0 & 8 & 0.874 & 0 & 0 & 0.089 & 2.404 & 1.633 & 0 & 0 & 5 \\
2 & 6.792 & 1.208 & 0 & 0 & 8 & 0.651 & 0 & 0 & 0.085 & 2.713 & 1.551 & 0 & 0 & 5 \\
3 & 6.423 & 1.577 & 0 & 0 & 8 & 0.901 & 0 & 0 & 0.05 & 2.256 & 1.792 & 0 & 0 & 5 \\
4 & 6.494 & 1.506 & 0 & 0 & 8 & 0.941 & 0 & 0 & 0.033 & 2.281 & 1.744 & 0 & 0 & 5 \\
5 & 6.561 & 1.439 & 0 & 0 & 8 & 0.951 & 0 & 0 & 0.018 & 2.28 & 1.751 & 0 & 0 & 5 \\
6 & 6.69 & 1.31 & 0 & 0 & 8 & 0.727 & 0 & 0 & 0.044 & 2.524 & 1.705 & 0 & 0 & 5 \\
7 & 6.353 & 1.647 & 0 & 0 & 8 & 0.887 & 0 & 0 & 0.074 & 2.337 & 1.702 & 0 & 0 & 5 \\
8 & 6.202 & 1.798 & 0 & 0 & 8 & 0.942 & 0 & 0 & 0.04 & 2.452 & 1.566 & 0 & 0 & 5 \\
9 & 6.37 & 1.63 & 0 & 0 & 8 & 0.979 & 0 & 0 & 0.044 & 2.225 & 1.752 & 0 & 0 & 5 \\
\hline sample & $\mathrm{BMg}$ & $\mathrm{BFe} 2$ & $\mathrm{BMn}$ & $\mathrm{BCa}$ & $\mathrm{BNa}$ & $\mathrm{Sum} \_\mathrm{B}$ & $\mathrm{ACa}$ & $\mathrm{ANa}$ & $\mathrm{AK}$ & $\mathrm{Sum} \_\mathrm{A}$ & $\mathrm{Sum} \_\mathrm{cat}$ & $\mathrm{CCl}$ & $\mathrm{CF}$ & Sum_oxy \\
\hline 1 & 0 & 0.142 & 0.001 & 1.807 & 0.05 & 2 & 0 & 0.409 & 0.113 & 0.523 & 15.523 & 0 & 0 & 22.996 \\
2 & 0 & 0.187 & 0.023 & 1.752 & 0.038 & 2 & 0 & 0.38 & 0.039 & 0.419 & 15.419 & 0 & 0 & 22.997 \\
3 & 0 & 0.117 & 0.019 & 1.864 & 0 & 2 & 0.013 & 0.476 & 0.066 & 0.555 & 15.555 & 0 & 0 & 22.996 \\
4 & 0 & 0.121 & 0.011 & 1.838 & 0.03 & 2 & 0 & 0.468 & 0.053 & 0.521 & 15.521 & 0 & 0 & 22.996 \\
5 & 0 & 0.114 & 0.004 & 1.858 & 0.025 & 2 & 0 & 0.42 & 0.051 & 0.47 & 15.47 & 0 & 0 & 22.996 \\
6 & 0 & 0.133 & 0.025 & 1.842 & 0 & 2 & 0.003 & 0.428 & 0.056 & 0.487 & 15.487 & 0 & 0 & 22.997 \\
7 & 0 & 0.155 & 0.022 & 1.818 & 0.005 & 2 & 0 & 0.531 & 0.078 & 0.61 & 15.61 & 0 & 0 & 22.996 \\
8 & 0 & 0.267 & 0 & 1.733 & 0 & 2 & 0.048 & 0.6 & 0.071 & 0.72 & 15.72 & 0 & 0 & 22.996 \\
9 & 0 & 0.143 & 0.03 & 1.802 & 0.025 & 2 & 0 & 0.523 & 0.056 & 0.579 & 15.579 & 0 & 0 & 22.996 \\
\hline
\end{tabular}


the amphiboles in greenschist is a member of the calcic group and Based on the $\mathrm{Mg} /\left(\mathrm{Mg}+\mathrm{Fe}^{2+}\right)$ on TSi diagram (Figure 12) shows the amphiboles in greenschist are of actinolite type. Actinolite is another green amphibole, although in thin-section the green color is much paler than that of hornblende. It may also be distinguished from hornblende by a lower extinction angle (typically around $15^{\circ}$ ). Actinolite is common in greenschist-facies metabasites, and along with two other green minerals (epidote and chlorite).

According to this $\mathrm{BNa}$ on $\mathrm{BCa}+\mathrm{BNa}$ diagram (Figure 13), shows the amphiboles in epidote amphibolite is a member of the calcic group and $\mathrm{Ba}$.

According to this BNa on BCa + BNa diagram (Figure 14), shows the amphiboles in amphibolite is a member of the calcic group and based on the $\mathrm{Mg} /\left(\mathrm{Mg}+\mathrm{Fe}^{2+}\right)$ on TSi diagram (Figure 15), shows this amphiboles are Magnesio-Hornblende type. Hornblende is a common constituent of metabasites of the amphibolite and granulite facies. Metamorphic hornblende tends to exhibit deep green color in contrast with igneous hornblende which tends to be brown.sed on the $\mathrm{Mg} /\left(\mathrm{Mg}+\mathrm{Fe}^{2+}\right)$ on TSi diagram (Figure 16), shows this amphiboles are tschermakite up to Ferro-Tschermakite + Ferro-Hornblende type.

\section{Mineral Chemistry of the Plagioclase Bearing Metabasits}

To determine the chemical composition of plagioclase bearing metabasites in the study area, electron microprobe analysis were done on this mineralization in greenschist, epidote amphibolite and amphibolite. Table 7

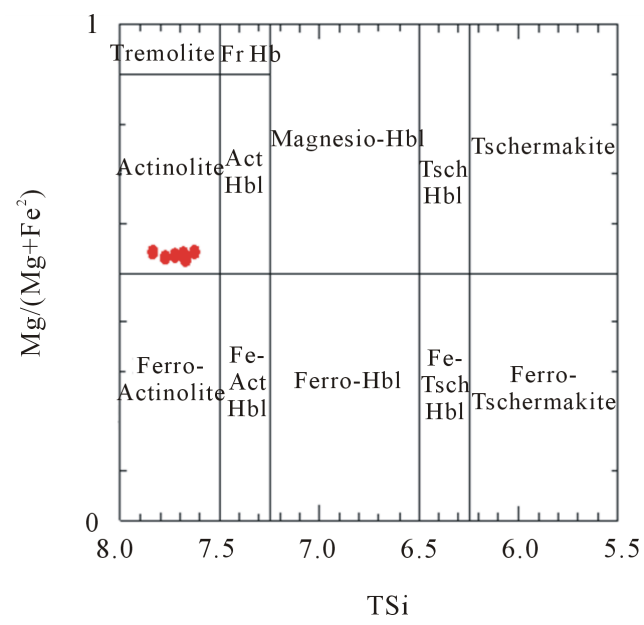

Figure 12. The $\mathrm{Mg} /\left(\mathrm{Mg}+\mathrm{Fe}^{2+}\right)$ on TSi diagram shows the amphiboles in greenschist are actinolite type.

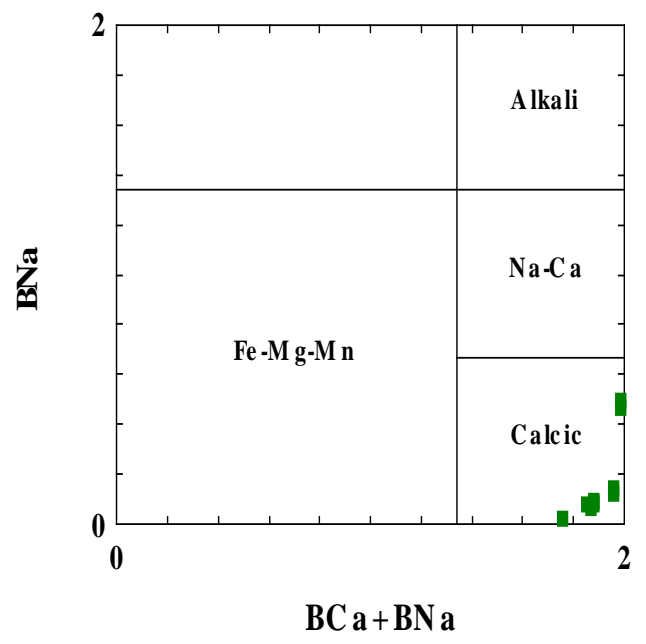

Figure 13. Chemical composition of the amphiboles analysed plotted on BNa on BCa + BNa diagram. The amphiboles in epidote amphibolite is a member of the calcic group. 


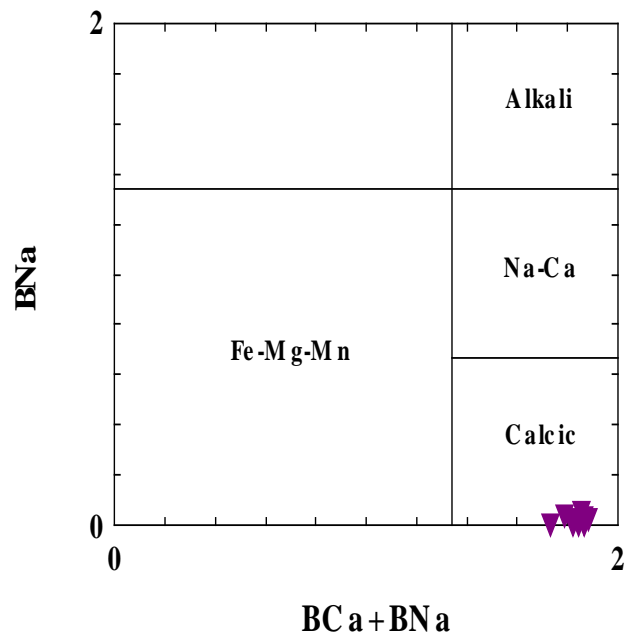

Figure 14. Chemical composition of the amphiboles analysed plotted on $\mathrm{BNa}$ on $\mathrm{BCa}+\mathrm{BNa}$ diagram. The amphiboles in amphibolite is a member of the calcic group.

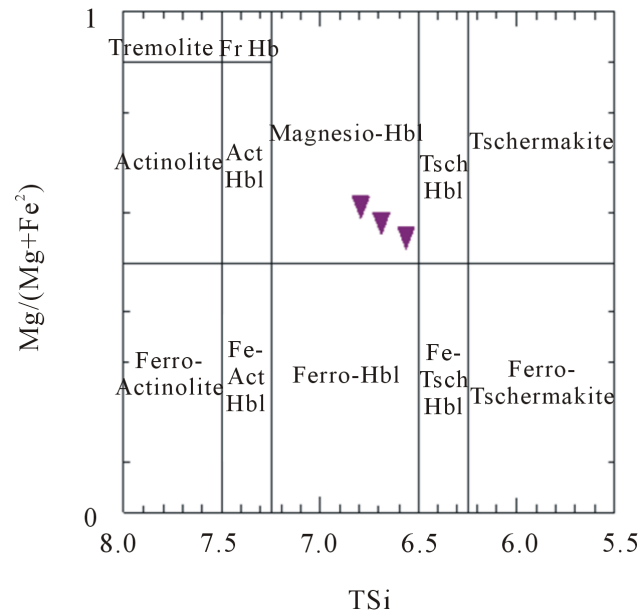

Figure 15. The $\mathrm{Mg} /\left(\mathrm{Mg}+\mathrm{Fe}^{2+}\right)$ on TSi diagram shows the amphiboles in amphibolite are hornblende type.

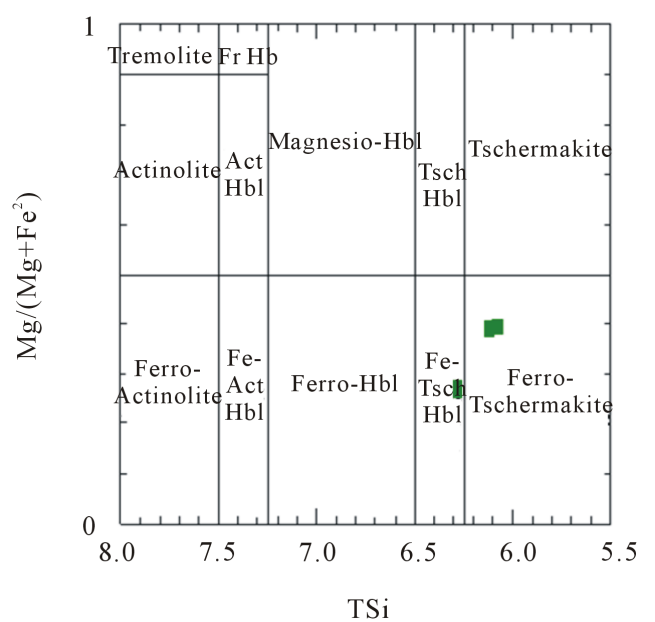

Figure 16. The $\mathrm{Mg} /\left(\mathrm{Mg}+\mathrm{Fe}^{2+}\right)$ on TSi diagram shows the amphiboles in epidote amphibolite are tschermakite up to Ferro-Tschermakite + Ferro-Hornblende type. 
includes the microprobe analyses of plagioclase in the greenschist samples. Table 8 includes the microprobe analyses of plagioclase in the epidote amphibolite samples. Table 9 includes the microprobe analyses of plagioclase in the amphibolite samples.

Based on the results of electron microprobe analysis, first by the Minpet Software, the number of cations is recalculated on the basis of 23 oxygens from the Deer et al. [8]. Table 10 includes the recalculated Result of plagioclase in the greenschist samples. Table 11 includes the recalculated Result of plagioclase in the epidote amphibolite samples. Table 12 includes the recalculated result of plagioclase in the amphibolite samples.

To determine the plagioclase mineral groups in metabasites of the study area, chemical composition of the plagioclases analysed plotted on Ab-An-Or diagram [1]. According to this diagram, shows the plagioclases in

Table 7. Microprobe analyses of plagioclase in the greenschist samples.

\begin{tabular}{cccccccccccc}
\hline Formula & $\mathrm{Na}_{2} \mathrm{O}$ & $\mathrm{K}_{2} \mathrm{O}$ & $\mathrm{MgO}$ & $\mathrm{CaO}$ & $\mathrm{FeO}$ & $\mathrm{Al} 2 \mathrm{O} 3$ & $\mathrm{SiO}_{2}$ & $\mathrm{TiO}_{2}$ & Total & $\mathrm{O}=$ & $\mathrm{Total}$ \\
\hline 1 & 10.87 & 1.1 & 0.1 & 0.71 & 0.09 & 20.32 & 67.56 & 0 & 100.75 & 100.75 \\
2 & 10.74 & 0.95 & 0.3 & 0.72 & 0.06 & 20.61 & 67.23 & 0 & 100.61 & 100.61 \\
3 & 10.82 & 1.07 & 0.13 & 0.74 & 0.07 & 20.75 & 67.38 & 0 & 100.96 & 100.96 \\
4 & 10.79 & 0.79 & 0.18 & 0.67 & 0.06 & 20.52 & 67.83 & 0 & 100.84 & 100.84 \\
5 & 10.93 & 0.67 & 0.15 & 0.78 & 0.04 & 20.49 & 67.28 & 0 & 100.34 & 100.34 \\
\hline
\end{tabular}

Table 8. Microprobe analyses of plagioclase in the epidote amphibolite samples.

\begin{tabular}{cccccccccccc}
\hline Formula & $\mathrm{Na}_{2} \mathrm{O}$ & $\mathrm{K}_{2} \mathrm{O}$ & $\mathrm{MgO}$ & $\mathrm{CaO}$ & $\mathrm{MnO}$ & $\mathrm{FeO}$ & $\mathrm{Al}_{2} \mathrm{O}_{3}$ & $\mathrm{SiO}_{2}$ & Total & $\mathrm{O}=$ & $\mathrm{Total}$ \\
\hline 1 & 8.24 & 0.09 & 0.02 & 4.79 & 0 & 0.73 & 24.03 & 63.31 & 101.21 & 101.21 \\
2 & 9.13 & 0.08 & 0 & 4.43 & 0 & 0 & 24.36 & 64.47 & 102.47 & 102.47 \\
3 & 9.74 & 0.04 & 0.02 & 4.28 & 0 & 0 & 22.17 & 62.12 & 98.36 & 98.36 \\
4 & 9.72 & 0.07 & 0 & 4.53 & 0 & 0.09 & 22.48 & 62.14 & 99.02 & 99.02 \\
\hline
\end{tabular}

Table 9. Microprobe analyses of amphibole in the amphibolite samples.

\begin{tabular}{ccccccccccccc}
\hline Formula & $\mathrm{Na}_{2} \mathrm{O}$ & $\mathrm{K}_{2} \mathrm{O}$ & $\mathrm{MgO}$ & $\mathrm{CaO}$ & $\mathrm{FeO}$ & $\mathrm{Al}_{2} \mathrm{O}_{3}$ & $\mathrm{Cr}_{2} \mathrm{O}_{3}$ & $\mathrm{SiO}_{2}$ & $\mathrm{TiO}_{2}$ & Total & $\mathrm{O}=$ & $\mathrm{Total}$ \\
\hline 1 & 9.97 & 0.08 & 0.04 & 3.69 & 0.01 & 26.41 & 0 & 60.38 & 0.1 & 100.68 & 100.68 \\
2 & 9.72 & 0.06 & 0 & 4.67 & 0.27 & 23.04 & 0.01 & 62.41 & 0.02 & 100.19 & 100.19 \\
3 & 9.73 & 0.08 & 0 & 4.41 & 0.05 & 22.85 & 0 & 62.95 & 0.89 & 100.96 & 100.96 \\
4 & 8.77 & 0.09 & 0 & 5.78 & 0 & 23.85 & 0 & 61.21 & 0.2 & 99.9 & 99.9 \\
5 & 9.03 & 0.09 & 0 & 5.9 & 0 & 23.88 & 0.01 & 60.86 & 0.4 & 100.18 & 100.18 \\
\hline
\end{tabular}

Table 10. Recalculated result of plagioclase in the epidote amphibolite samples.

\begin{tabular}{cccccccccccccc}
\hline Formula & $\mathrm{Si}$ & $\mathrm{Al}$ & $\mathrm{Ti}$ & $\mathrm{Fe}_{2}$ & $\mathrm{Mn}$ & $\mathrm{Mg}$ & $\mathrm{Ca}$ & $\mathrm{Na}$ & $\mathrm{K}$ & Cations & $\mathrm{Ab}$ & $\mathrm{An}$ & $\mathrm{Or}$ \\
\hline 1 & 11.796 & 4.178 & 0 & 0.013 & 0 & 0.026 & 0.133 & 3.68 & 0.245 & 20.071 & 90.7 & 3.3 & 6 \\
2 & 11.744 & 4.24 & 0 & 0.009 & 0 & 0.078 & 0.135 & 3.638 & 0.212 & 20.056 & 91.3 & 3.4 & 5.3 \\
3 & 11.739 & 4.257 & 0 & 0.01 & 0 & 0.034 & 0.138 & 3.655 & 0.238 & 20.071 & 90.7 & 3.4 & 5.9 \\
4 & 11.8 & 4.204 & 0 & 0.009 & 0 & 0.047 & 0.125 & 3.64 & 0.175 & 20 & 92.4 & 3.2 & 4.4 \\
5 & 11.771 & 4.222 & 0 & 0.006 & 0 & 0.039 & 0.146 & 3.708 & 0.15 & 20.042 & 92.6 & 3.6 & 3.7 \\
\hline
\end{tabular}

Table 11. Recalculated result of plagioclase in the epidote amphibolite samples.

\begin{tabular}{cccccccccccccc}
\hline Formula & $\mathrm{Si}$ & $\mathrm{Al}$ & $\mathrm{Ti}$ & $\mathrm{Fe}_{2}$ & $\mathrm{Mn}$ & $\mathrm{Mg}$ & $\mathrm{Ca}$ & $\mathrm{Na}$ & $\mathrm{K}$ & $\mathrm{Cations}$ & $\mathrm{Ab}$ & $\mathrm{An}$ & $\mathrm{Or}$ \\
\hline 1 & 11.075 & 4.95 & 0 & 0.107 & 0 & 0.005 & 0.898 & 2.795 & 0.02 & 19.85 & 75.3 & 24.2 & 0.5 \\
2 & 11.112 & 4.944 & 0 & 0 & 0 & 0 & 0.818 & 3.051 & 0.018 & 19.943 & 78.5 & 21 & 0.5 \\
3 & 11.197 & 4.706 & 0 & 0 & 0 & 0.005 & 0.827 & 3.404 & 0.009 & 20.148 & 80.3 & 19.5 & 0.2 \\
4 & 11.144 & 4.748 & 0 & 0.013 & 0 & 0 & 0.87 & 3.38 & 0.016 & 20.171 & 79.2 & 20.4 & 0.4 \\
\hline
\end{tabular}


the greenschist the plagioclase is pure albite (An3.29 - 3.6) (Figure 17), and in the epidote amphibolite the plagioclase is oligoclase (An19.5 - 24.2) (Figure 18), while in the amphibolites the plagioclase is oligoclase (An 16.9 - 26.6) (Figure 19).

\section{P-T Estimates}

In general, the calculation of pressure-temperature (P-T) conditions of metamorphism of the Tanbour metabasite is hampered by the absence of suitable mineral phases such as garnet. However, some conventional quantitative geothermometers and geobarometers are available including hornblende-plagioclase geothermometry.

Table 12. Recalculated result of plagioclase in the amphibolite samples.

\begin{tabular}{cccccccccccccccccc}
\hline Formula & $\mathrm{Si}$ & $\mathrm{Al}$ & $\mathrm{Ti}$ & $\mathrm{Fe} 2$ & $\mathrm{Mn}$ & $\mathrm{Mg}$ & $\mathrm{Ca}$ & $\mathrm{Na}$ & $\mathrm{K}$ & $\mathrm{Cations}$ & $\mathrm{Ab}$ & $\mathrm{An}$ & $\mathrm{Or}$ \\
\hline 1 & 10.654 & 5.488 & 0.013 & 0.001 & 0 & 0.011 & 0.698 & 3.411 & 0.018 & 20.294 & 82.7 & 16.9 & 0.4 \\
2 & 11.078 & 4.816 & 0.003 & 0.04 & 0 & 0 & 0.888 & 3.345 & 0.014 & 20.184 & 78.8 & 20.9 & 0.3 \\
3 & 11.075 & 4.734 & 0.118 & 0.007 & 0 & 0 & 0.831 & 3.319 & 0.018 & 20.102 & 79.6 & 19.9 & 0.4 \\
4 & 10.903 & 5.003 & 0.027 & 0 & 0 & 0 & 1.103 & 3.029 & 0.02 & 20.085 & 73 & 26.6 & 0.5 \\
5 & 10.839 & 5.008 & 0.054 & 0 & 0 & 0 & 1.126 & 3.118 & 0.02 & 20.165 & 73.1 & 26.4 & 0.5 \\
\hline
\end{tabular}

\section{Or}

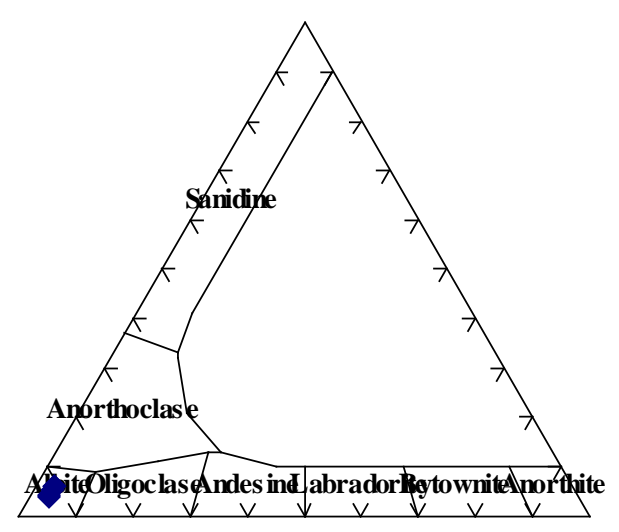

\section{Ab}

An

Figure 17. The Ab-An-Or diagram shows the plagioclases in greenschist are albite type.

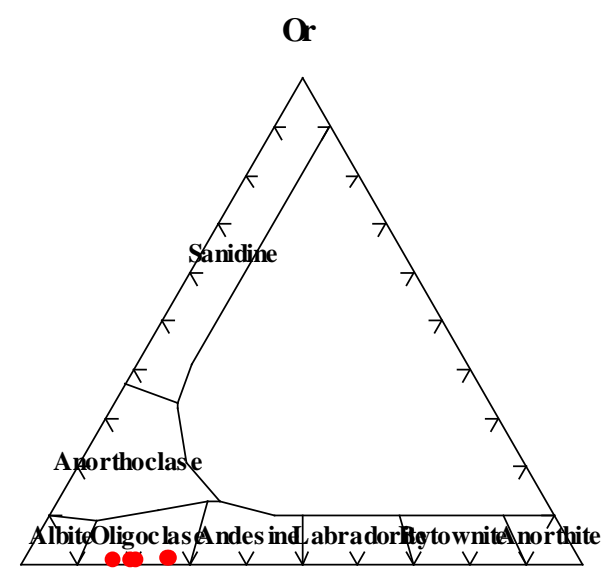

Ab

An

Figure 18. The Ab-An-Or diagram shows the plagioclases in epidot amphibolite are oligoclase type. 


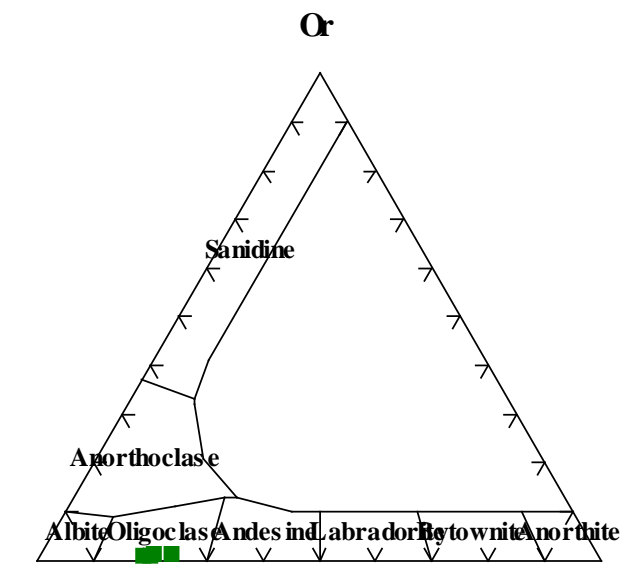

Ab An

Figure 19. The Ab-An-Or diagram shows the plagioclases in amphibolite are oligoclase type.

\section{Hornblende-Plagioclase Geothermometry}

Temperatures during metamorphism of the Tanbour metabasite have been estimated using the hornblende-plagioclase thermometer of Holland and Blundy [9]. This thermometer is based on the Ca and Na equilibrium exchange between plagioclase and amphibole. The temperatures were calculated for plagioclase-amphibole pairs that show clear contacts at their boundaries from samples of amphibolites and epidote amphibolites. Due to the presence of quartz in the assemblages, the edenite-tremolite, rather than edenite-richterite, equilibrium expression of the hornblende-plagioclase thermometer was used [9]. This calibration has reported an uncertainty of $\pm 75^{\circ} \mathrm{C}$. The Hb-PLAG software, provided by Tim Holland, has been used for calculation. For a given pressure of $8 \mathrm{kbar}$, temperatures of $550^{\circ} \mathrm{C}$ and pressure of $10.5 \mathrm{kbar} 611^{\circ} \mathrm{C}-652^{\circ} \mathrm{C}$ were estimated for epidote amphibolites and amphibolites, respectively.

\section{Conclusion}

Amphibole and plagioclase are the main minerals in the greenschist and amphibolite. Based on the results of electron microprobe analysis, the amphiboles in greenschist is a member of the calcic group and actinolite type. Therefore it can be called these metamorphic rocks, actinolite schist with this mineralogy paragenesis is represented to the greenschist metamorphic facies. The amphibole in epidote amphibolite is a member of the calcic group and this amphibole is tschermakite up to Ferro-Tschermakite + Ferro-Hornblende type. These rocks are named epidote amphibolite, because with this mineralogy paragenesis, they are represented to the epidote-amphibolite metamorphic facies, the transition between greenschist facies and amphibolite facies. The amphibole in amphibolite is a member of the calcic group and this amphibole is Magnesio-Hornblende type. The plagioclases in the greenschist is pure albite (An3.29 - 3.6), and in the epidote amphibolite is oligoclase (An19.5 - 24.2), while in the amphibolites is oligoclase (An16.9 - 26.6). The estimated P-T conditions are in favor of their metamorphism under epidote amphibolite $\left(550^{\circ} \mathrm{C}\right.$ and $\left.8 \mathrm{kbar}\right)$ and amphibolite $\left(611^{\circ} \mathrm{C}-652^{\circ} \mathrm{C}\right.$ and 10.5 kbar) facies.

\section{References}

[1] Moazzen, M. (1993) Study of the Kuh-e-Tanbour Metamorphic Complex with Special Reference to the Garnet-Rich Layers (Unpublished M.Sc. Thesis). Kerman University, Iran, 162 p.

[2] DimitriVic, M. (1973) Geology of Kerman Region. Report No. 52/YU, Iranian Geological Survey.

[3] Mijalkovic, N. and Saric, V. (1973) Exploration for ore deposits in Kerman region. Report No. YU/53, Geological Survey of Iran.

[4] Leake, B.E., et al. (1997) Nomenclature of Amphiboles: Report of the Subcommittee of the International Mineralogical Association, Commission on New Minerals and Mineral Names. American Mineralogist, 82, 1019-1037.

http://dx.doi.org/10.1180/minmag.1997.061.405.13 
[5] Richard, L.R. and Clarke, D.B. (1990) AMPHIBOL: A Program for Calculating Structural Formulae and for Classifying and Plotting Chemical Analyses of Amphiboles. American Mineralogist, 75, 421-423.

[6] Robinson, P., Spear, F.S., Schumacher, J.C., Laird, J., Klein, C., Evans, B.W. and Doolan, B.L. (1981) Crystal Chemistry of Amphiboles. In: Veblen, D.R. and Ribbe, P.H., Eds., Volume 9B: Amphiboles: Petrology and Experimental Phase Relations, Mineralogical Society of America, 1-227.

[7] Hawthorne, F.C. (1981) Crystal Chemistry of the Amphiboles. Canadian Mineralogist, 21, 173-480.

[8] Deer, W.A., Howie, R.A. and Zussman, J. (1992) An Introduction to the Rock Forming Minerals. Longman Scientific \& Technical, England; Wiley, New York.

[9] Holland, T. and Blundy, J. (1994) Plagioclase-Hornblende Thermobarometry (Temperature by Holland and Blundy, 1994; Blundy and Holland, 1990; at Pressure by Schmidt, 1992 and Anderson and Smith, 1995). 